\title{
New genotypic adaptability and stability analyses using Legendre polynomials and genotype-ideotype distances
}

4 Michel Henriques de Souza ${ }^{1 *}$, José Domingos Pereira Júnior ${ }^{1}$, Skarlet De Marco Steckling ${ }^{2}$, 5 Jussara Mencalha ${ }^{1}$, Fabíola dos Santos Dias ${ }^{1}$, João Romero do Amaral Santos de Carvalho 6 Rocha ${ }^{2}$, Pedro Crescêncio Souza Carneiro ${ }^{2}$, José Eustáquio de Souza Carneiro ${ }^{1}$

1Departamento de Agronomia, Universidade Federal de Viçosa, Viçosa, CEP: 36570-900, Minas Gerais, Brazil.

${ }^{2}$ Departamento de Biologia Geral, Universidade Federal de Viçosa, Viçosa, CEP: 36570-900, Minas Gerais, Brazil.

*Corresponding author - email: micheel.1992@gmail.com 


\section{Introduction}

The main objective of a crop breeding program, is to develop cultivars that can replace those that are currently available [1]. In the final stages of a breeding program, the most promising lines are evaluated in trials conducted in different environments, such as different years, places, and seasons. In Brazil, these tests are called Valor de Cultivo e Uso (VCU), and their results are the basis for the cultivar recommendation [2].

Adaptability and stability studies are used to quantify the performances of the genotypes to make recommendations [3]. Adaptability is defined as the ability of a genotype to respond advantageously to its environment, while its stability is related to the predictability of its behavior $[4,5]$. It is thus possible to identify genotypes that have wide or specific adaptability to favorable or unfavorable environments. Finlay and Wilkinson [4] defined favorable and unfavorable environments as those that result in the average performance of the genotype being above or below the average of all the trials, respectively.

Genotypes that have specific adaptability to favorable environments, have genes that enable them to respond to improved environmental conditions, and should be recommended to farmers who wish to utilize the most current technologies. Genotypes with specific adaptability to unfavorable environments however, may have specific genes that enable them to grow in these environments. These are rustic genotypes and should be recommended to farmers who utilize lower level technologies. In general, rustic genotypes have more genes that tolerate biotic and abiotic stresses, which means they may be favored in more adverse environmental conditions.

In recent decades, several methods to analyze adaptability and stability have been proposed, based on different statistical principles. To identify genotypes that have general or 
specific adaptability to favorable (requires a high level of technology) or unfavorable (requires a low level of technology) environments, methodologies that are based on linear regression models have shown promise [4-7]. Some of the previous methods to determine the adaptability and stability included the ideotype concept [8-11], and resulted in an improved understanding of the relative behavior of the genotypes from a smaller number of parameters. According to Eeuwijk et al. [12], there are other methodologies to assess the behavior of genotypes that are of note, such as AMMI (Additive Main effects and Multiplicative Interaction) [13] and GGE biplot (Genotype main effects and Genotype x Environment interaction effects) [14]. However, the adaptability and stability analyses still have limitations, especially when used with trials with genetic or statistical imbalances, heterogeneity of residual variances, and genetic covariance. In this context, adaptability and stability analyses that use a mixed model approach are an effective alternative to the traditional analyses $[15,16]$.

Another relevant factor is that traditional methodologies for the analysis of adaptability and stability, consider a priori, that the behavior of a genotype across environments is linear, which may not be true. As a consequence, recommendations based on these methodologies can be biased. This can be outlined by means of reaction norm models via mixed modeling, as they allow for improved modeling of the behavior of the different genotypes, based mostly on orthogonal polynomials. Among this class of polynomials, the Legendre's polynomials stand out, as they have the ability to describe the structures of variance and covariance between the genetic and environmental components [17].

In this way, the use of the reaction norms obtained from the Legendre polynomials can better quantify the adaptability and stability of a set of genotypes evaluated in different environments, aiming for greater accuracy in cultivar recommendations. Thus, the objectives of this investigation were to propose a new methodology for the analysis of adaptability and genotypic stability, based on Legendre polynomials and genotype-ideotype distances. 


\section{Methods description (step by step)}

85 Step one: Environmental gradient this gradient, trials in which the genotypes are evaluated must be ordered a priori, according to certain classification criteria such as Akaike Information Criterion (AIC) [18], Bayesian Information Criterion (BIC) [19], and Penalizing Adaptively the Likelihood (PAL) [20]. We consequently recommend the index proposed by Finlay and Wilkinson [4], since the adaptability of a genotype is its ability to respond to environmental improvements. The environmental index was determined as follows:

$$
I_{j}=\left(\bar{Y}_{j}-\bar{Y}\right)
$$

where $\bar{Y}_{j}$ is the average of the genotypes $j$-th trial $(j=1,2, \ldots, n a$, where $n a$ is the total number of trials) and $\bar{Y}$ is the general mean. Negative and positive index values indicate unfavorable and favorable trials, respectively. 
The number of models to be tested depends on the number of trials used (determines the maximum order of the polynomial), the number of effects included in the model via the Legendre polynomials, and the residual covariance structures. adopted was as follows:

$$
y_{i j k}=A_{j}+R / A_{j k}+\sum_{m=0}^{M-1} \alpha_{i m} \Phi_{i j m}+e_{i j k}
$$

where: $y_{i j k}$ is the observation of the $i$-th genotype $(i=1,2, \ldots, n g$, where $n g$ is the total number of genotypes), in the $j$-th trial $(j=1,2, \ldots, n a$, where $n a$ is the total number of trials), in the $k$-th block $(k=1,2,3) ; A_{j}$ is the effect of the trial; $R / A_{j k}$ is the fixed effect of the blocks within each trial; $\alpha_{i m}$ is the reaction norm coefficient for the Legendre polynomial of order $m$ for the genotypic effects of the genotypes; $\Phi_{i j m}$ is Legendre's $m$-th polynomial for the $j$-th trial, standardized from -1 to +1 for the $i$-th genotype; $M$ is the order of adjustment of the Legendre polynomial for genotypic effects; and $e_{i j k}$ is the residual random effect associated with $y_{i j k}$. of phenotypic data; $b$ is the vector of the fixed effects of the combination of blocks $\times$ trials added to the general average; $g$ is the vector of genetic effects (assumed to be random); and $e$ is the residue vector (random). $X$ and $Z$ represent the incidence matrix for these effects, respectively. It is assumed that: $g \sim \mathrm{N}\left(0, K g \otimes I_{n g}\right)$, and $e \sim \mathrm{N}\left(0, I_{n p} \otimes \sum\right)$, where $I_{n g}$ and $I_{n p}$ are identity matrices of the order $n g$ ( $n g$ is the total number of genotypes) and $n p$ ( $n p$ is the 
125

126

127

128

129

130 number of parameters for the models. represents the matrix of residual variances. are described as follows:

where;

number of genotypes $\mathrm{x}$ the number of blocks), respectively. The symbol $\otimes$ denotes the Kronecker product. $\mathrm{Kg}$ is the matrix of covariance coefficients for genotypic effect. $\Sigma$

\section{Step three: Choosing the best fit model}

To select the best fit model, criteria the AIC, BIC and PAL were utilized. These criteria

$$
A I C=-2 \ln L+2 p
$$

$$
B I C=-2 \ln L+p \ln [n-r(x)]
$$

$$
P A L=-2 \ln L+n \ln (\tilde{\mathrm{n}}) \frac{\ln \left(r_{n}+1\right)}{\ln \left(\rho_{n}+1\right)}
$$

and $\ln L$ is the logarithm of the likelihood function; $p$ is the number of estimated parameters; $n$ is the number of observations; $r(x)$ is the rank of the fixed effects matrix; and $\tilde{n}$ is the highest 


\section{Step four: Genetic effects significance} as follows:

where: $\log L_{\text {mod.r }}$ is the logarithm value of the maximum likelihood function obtained for the reduced model (without the genotypic effect), and $\log L_{\text {mod.c }}$ is the logarithm value of the maximum likelihood function obtained for the complete model. 
162

163

where: $\hat{\alpha}_{i m}$ is the reaction norm coefficient of order $m$ for the genetic effects of the $i$-th genotype. This equation includes a transformation to the original scale, as using the Legendre polynomials as a covariate affects the scale of the genotypic values.

\section{Step six: Accuracy at the original scale} equation:

The prediction accuracy, also in original scale, is estimated according to the following

$$
r_{\hat{g} g_{i j}}=\sqrt{1-\frac{\Phi_{i j m} P E V_{i j} \Phi_{i j m}^{\prime}}{\Phi_{i j m} \hat{K}_{g} \Phi_{i j m}^{\prime}}}
$$

where: $r_{\hat{g} g_{i j}}$ is the correlation between the predicted and real genotype values for genotype $i$ in trial $j$, that is, the estimated accuracy; $P E V_{i j}$ is the Predicted Error Variance of the estimated coefficients for genotype $i$ in trial $j ; \hat{K}_{g}$ is the covariance matrix of the coefficients, estimated for the genotypic effect.

\section{Step seven: Genotypic adaptability and stability}

To quantify the adaptability and stability of the genotypes, we proposed the use of the genotype-ideotype distance (converted into probability), using four ideotypes: i) genotypes of general adaptability (genotypes of maximum performance in both unfavorable and favorable 
environments); ii) genotypes of maximum adaptability to unfavorable environments (genotypes of maximum performance in unfavorable environments, regardless of their performance in

184 favorable environments); iii) genotypes of maximum adaptability to favorable environments (genotypes of maximum performance in favorable environments, regardless of their performance in unfavorable environments); and iv) genotypes with minimal adaptability. according to the estimator below:

$$
P_{i k}=\frac{\frac{1}{G I D_{i k}}}{\sum_{i=1}^{n g} \frac{1}{G I D_{i k}}}
$$

$192 P_{i k}$ are the probabilities referring to genotype $i$ with regard to ideotype $k(k=1,2,3,4$; where 1 = genotypes of general adaptability; 2 = genotypes of maximum adaptability to unfavorable environments; 3 = genotypes of maximum adaptability to favorable environments; and $4=$ genotypes of minimal adaptability); and $n g$ is the total number of genotypes. $G I D_{i k}$ is the standardized average Euclidean distance for genotype $i$ in ideotype $k$, as given by:

$$
G I D_{i k}=\sqrt{\frac{\sum_{j}\left[\hat{g}_{i j}-i d e\left(\hat{g}_{i j}\right)\right]^{2}}{n j}}
$$


where, if $k=1, j=1, \ldots, n a$; if $k=2, j=1, \ldots, n d$; if $k=3, j=1, \ldots, n f$; if $k=4, j=1, \ldots, n a$; and

$n a$ is the highest assumed value for $j$; $n d$ and $n f$ represent the number of unfavorable and favorable environments, respectively; ide $\left(\hat{g}_{i j}\right)$ is the ideotype drawn from the standardized genotypic values.

It is important to emphasize that the estimators proposed above also considered the environment trials (MET).

We recommend evaluating the performance only in those genotypes that present an accuracy value of at least $80 \%$ in the trials, since the accuracy is indicative of the precision in the prediction of genotypic values. Thus, the average accuracy of the trials considered in the cultivar recommendation will also show values equal to or greater than $80 \%$. The standard value is based on that of Resende and Duarte [23], who claimed to have at least $80 \%$ accuracy values in VCU trials, when assessing the values of their cultivars.

\section{Application of the method with Phaseolus vulgaris $L$.}

219 Carioca grains and 49 were Black grains. These are the cultivars that have been recommended 


\section{Trials}

The trials were conducted in different environments (seasons, years, and places), during the dry and winter seasons, between 2013 and 2018, at the Experimental Stations in Coimbra county - Minas Gerais (Unidade de Ensino, Pesquisa e Extensão - UEPE Coimbra: latitude $20^{\circ} 49^{\prime} 44^{\prime \prime} \mathrm{S}$, longitude $42^{\circ} 45^{\prime} 56^{\prime \prime} \mathrm{W}$ and altitude of 713 meters) and Viçosa - Minas Gerais Nova: latitude $20^{\circ} 45^{\prime} 47^{\prime \prime} \mathrm{S}$, longitude $42^{\circ} 49^{\prime} 25^{\prime \prime} \mathrm{W}$ and altitude of 664 meters; Vale da Agronomia: latitude $20^{\circ} 46^{\prime} 04^{\prime \prime} \mathrm{S}$, longitude $42^{\circ} 52^{\prime} 11^{\prime \prime} \mathrm{W}$ and altitude of 662 meters), thus each MET consisted of 13 trials. Over the years in which the trials were carried out, the cultivars that were recently launched by the breeding programs were included, thus causing a genetic imbalance (variation in the number of cultivars in the trials). The 13 trials and their characteristics are listed in S3 table (supporting information). consisted of four lines of two meters (m), spaced $0.5 \mathrm{~m}$ apart. The treatments used were in accordance with the recommendations for common bean cultures [24]. The evaluated characteristic was grain yield, and they were harvested from the two central lines of each plot. The data were corrected to $13 \%$ humidity and converted to $\mathrm{kg} \mathrm{ha}^{-1}$.

\section{Data analysis}



yield in the MET, with trials ordered according to the environmental index. Among these models, seven were tested considering the homogeneous residual variance and the other seven with heterogeneous diagonal residual variance. The models were adjusted with Legendre's polynomials, considering the various adjustment orders and based on the general model presented in Eq. 2. model (lowest mean square error and greater parsimony). The reaction norm models were compared using the AIC (Eq. 3), BIC (Eq. 4), and PAL (Eq. 5) criteria. The LRT test, presented in Eq. 6, was used to test the significance of the genetic effects. The genotypic values for each estimated according to Eq. 8 .

By using the BLUPs, the adaptability and stability of the cultivars were determined, aiming at the recommendations of the cultivars. In this way, we have calculated the probabilities for the recommendations of the cultivars, using the distance of the genotypes in the functions of the ideotypes. The probability values were obtained using Eq. 9.

To view the results, the ten cultivars with the highest probability were selected to plot their curves with their respective reaction norms, for the three ideotypes, as we chose not to include ideotype IV, since it makes no sense to recommend cultivars of minimal adaptability. The BLUP of each cultivar was added, plus the environment average, and the general average, as well as two witnesses, Pérola (Carioca bean) and Ouro Negro (Black bean), for comparison purposes. These two cultivars were selected as witnesses, as they are used as references for the 
268 productivity and quality of grain in consumer markets for the Carioca and Black beans, respectively [25]. The accuracy values (S4 table) and recommendation probability values (S5 table) are available in the supporting information.

\section{Software used} available in the S1 code.

\section{Results} unfavorable ones [3]. Trials 12, 9, 4, 10, 8, and 6 were classified as unfavorable environments, while trials $5,2,3,7,1,11$, and 13 were favorable 
Table 1: Trials evaluated with their environmental index.

\begin{tabular}{|c|c|c|}
\hline Trial & Description & Environmental gradient \\
\hline 12 & Dry/2017/Aeroporto & -1028.89 \\
\hline 9 & Dry/2016/UEPE Coimbra & -668.67 \\
\hline 4 & Winter/2013/Vale da Agronomia & -500.76 \\
\hline 10 & Winter/2016/UEPE Coimbra & -466.43 \\
\hline 8 & Dry/2016/Aeroporto & -167.35 \\
\hline 6 & Winter/2015/UEPE Coimbra & 31.02 \\
\hline 5 & Dry/2015/UEPE Coimbra & 106.80 \\
\hline 2 & Dry/2013/Vale da Agronomia & 127.71 \\
\hline 3 & Winter/2013/Coimbra & 259.39 \\
\hline 7 & Dry/2016/UEPE Coimbra & 786.60 \\
\hline 1 & Dry/2013/Coimbra & 1868.83 \\
\hline 11 & Winter/2016/Horta Nova & \\
\hline 13 & Winter/2017/UEPE Coimbra & \\
\hline
\end{tabular}
for the residues and a grade six for the Legendre polynomials, as having the best fit (Table 2).

The BIC and PAL criteria however, identified the Leg.5.D model as having the best fit. The AIC and BIC criteria prioritize, respectively, efficiency and consistency in their choices of model [28,29]. Corrales et al. [29], using simulated data, reported that when the true model was among the candidate models, the PAL and BIC criteria selected the same model. Furthermore, when the PAL and AIC criteria were used, the model selection was not always the same. When the real model was unknown, the AIC was more precise in choosing the best model, compared to the BIC. According to Vrieze [30], for very complex models (which include a high number of parameters) the BIC criterion was preferred over the AIC. Corrales et al. [29] stated that the 
302 PAL criterion simultaneously considers the consistency and efficiency of a model and should,

303 therefore, be preferred over the AIC and BIC criteria when choosing models. The model

304 ultimately chosen was Leg.5.D.

Based on the chosen model (Leg.5.D), the random effects of the cultivars were modeled as linear functions using the Legendre polynomials, with grade five and heterogeneous residual variance (diagonal). This resulted in 34 estimated parameters, 13 of which were associated with residues, that is, one for each trial, and 21 related to the model's genotypic components. It is of note that the genetic effect was significant with the LRT test for all fitted models, indicating

310 high variability between the cultivars evaluated (Table 2).

Table 2. Different fitted models using the Legendre polynomials (Leg).

\begin{tabular}{|c|c|c|c|c|c|c|c|}
\hline Model $^{1}$ & DEG & $p$ & LOG L & AIC & BIC & PAL & LRT \\
\hline Leg.0.H & 0 & 2 & Converged & 11307 & 11319 & 11303 & 377.68 \\
\hline Leg.1.H & 1 & 4 & Converged & 11288 & 11312 & 11280 & 400.6 \\
\hline Leg.2.H & 2 & 7 & Converged & 11255 & 11299 & 11257 & 438.8 \\
\hline Leg.3.H & 3 & 11 & Converged & 11218 & 11286 & 11229 & 484.1 \\
\hline Leg.4.H & 4 & 16 & Converged & 11191 & 11291 & 11217 & 520.7 \\
\hline Leg.5.H & 5 & 22 & Converged & 11150 & 11286 & 11197 & 574.5 \\
\hline Leg.6.H & 6 & 29 & Converged & 11134 & 11315 & 11243 & 603.7 \\
\hline Leg.0.D & 0 & 14 & Converged & 11007 & 11094 & 10979 & 507.6 \\
\hline Leg.1.D & 1 & 16 & Converged & 10983 & 11083 & 10951 & 534.9 \\
\hline Leg.2.D & 2 & 19 & Converged & 10928 & 11046 & 10930 & 595.9 \\
\hline Leg.3.D & 3 & 23 & Converged & 10865 & 11008 & 10885 & 667.2 \\
\hline Leg.4.D & 4 & 28 & Converged & 10740 & 10914 & 10779 & 802.7 \\
\hline Leg.5.D & 5 & 34 & Converged & 10648 & 10859 & 10730 & 906.2 \\
\hline Leg.6.D & 6 & 41 & Converged & 10645 & 10900 & 10881 & 922.9 \\
\hline
\end{tabular}


313 Model structure, degree polynomial for the genetic effect (DEG), number of parameters (p),

314 LOG L convergence, Akaike information criterion (AIC), Schwarz Bayesian information

315 criterion (BIC), Penalizing adaptively the likelihood (PAL) and Likelihood Ratio Test (LRT).

$316{ }^{1}$ The tested models can assume homogeneous $(\mathrm{H})$ or diagonal $(\mathrm{D})$ residual variance structure.

The average accuracy for the prediction of the BLUPs for each cultivar, based on the

Leg.5.D model, are shown in Fig 1. We found that the average accuracy of predictions was

greater when more trials were used to evaluate the cultivars. The accuracy observed for the

cultivars that were present in the 13 environments was the highest, while the accuracy estimates

for the cultivars evaluated in only two environments were the lowest. It can also be seen in

figure 1, that in trials six and eight (ordered according to the environmental gradient), the accuracy estimates were relatively low. It is also noteworthy that the estimates of genotypic

Fig 1: Average accuracy of the prediction in each trial for the genotypic values of the cultivars.

a) Cultivars evaluated in 13 trials (80 cultivars); b) cultivars evaluated in nine trials (20 cultivars); c) cultivars evaluated in six trials (four cultivars); and d) cultivars evaluated in only two trials (one cultivar). The trials are ordered according to the environmental index (Table 1).

Using the proposed reaction norm methodology, the adaptability and stability of 100 of the 105 cultivars was quantified. These 100 cultivars were evaluated in at least nine of the 13 trials, with the accuracy in predicting their genotypic values, equal to or greater than $80 \%$, including for those trials in which the cultivars were not evaluated (S4 table). 

proposed ideotypes (four scenarios): cultivars of general adaptability, cultivars of maximum adaptability to unfavorable environments, cultivars of maximum adaptability to favorable environments, and cultivars of minimal adaptability. The probability values of each cultivar in each scenario are presented in S5 table.

Fig 2 shows the reaction norm curves of the ten bean cultivars with the highest potential (highest probability value), considering the general adaptability scenario (ideotype - maximum performance genotypes in both unfavorable and favorable environments), as well as the cultivars used as witnesses (Pérola and Ouro Negro). The probability of each cultivar was calculated according to eq. 9 , in relation to the ideotype for the scenario of general adaptability.

Among the ten selected cultivars, six had the Carioca grain type (BRS Estilo, IAC Formoso, type (BRS Agreste, IPR Tiziu, IPR Tuiuiú and VP 22). The IPR Campos Gerais cultivar surpassed the Pérola cultivar in all trials, while the VP 22 cultivar surpassed the Ouro Negro cultivar in all trials.

\section{Fig 2: Cultivars of Carioca and Black bean of general adaptability according to the} ideotype.

The trials are ordered according to the environmental index (Table 1). ${ }^{*}$ Cultivars used as witnesses.

The reaction norm curves of the ten bean cultivars with the greatest potential (highest probability value), considering the scenario of maximum adaptability to unfavorable environments (ideotype - maximum performance genotypes in unfavorable environments, 
regardless of their performance in favorable environments), as well as the cultivars used as witnesses, are presented in Fig 3. Of the ten selected cultivars, seven had Carioca grain (BRS cultivars exceeded the Ouro Negro cultivar.

Fig 3: Cultivars of Carioca and Black bean of maximum adaptability for unfavorable environments according to the ideotype.

The trials are ordered according to the environmental index (Table 1). *Cultivars used as witnesses.

In Fig 4, the reaction norm curves for the ten cultivars with the highest potential (highest probability value), considering the scenario of maximum adaptability to favorable environments (ideotype - maximum performance genotypes in favorable environments, regardless of their performance in unfavorable environments), as well as the cultivars used as a witness, are shown. Of the ten selected cultivars, seven had Carioca grain (BRS Estilo, IAC Formoso, IAC Imperador, IPR Andorinha, IPR Campos Gerais, IPR 139 and VC 15) and three had Black grain (IPR Agreste, IPR Tuiuiú and VP 22). The IPR Campos Gerais cultivar surpassed the Pérola cultivar, in all trials, and the IPR Agreste, IPR Tuiuiú, and VP 22 black bean cultivars exceeded the Ouro Negro cultivar, in all trials.

Fig 4: Cultivars of Carioca and Black bean of maximum adaptability for favorable 
384 The trials are ordered according to the environmental index (Table 1). *Cultivars used as witnesses.

\section{Discussion}

Rating the variations of a set of trials, according to an environmental gradient, is essential when using methods based on linear regression that aim to quantify the adaptability of a cultivar. Finlay and Wilkinson [4] proposed using the average performances of the cultivars in each trial as a gradient, and estimating an environmental index using the differences between the average of the cultivars evaluated in each trial and the general average of the cultivars in all trials. Additionally, the fit of the regression model for each cultivar was made according to its performance, relative to the environmental index, in order to increase the values. The lack of an environmental gradient complicates the interpretation of the behavior of the genotypes in the face of the environmental variations [4].

When classifying the trials with the environmental index (in favorable or unfavorable environments), it was observed that the seasons, places, and years in which the trials were conducted did not determine the classification, as the trials from the same place and year could have very different results (trials 7 and 9), while those from different seasons, places, and years could be very similar (for example, environments 1 and 11). It should be noted that trial 9 was planted 44 days after trial 7, which may be one of the justifications for the different environmental index values. These results could be caused by edaphoclimatic variations, as well as variations in the incidence of pests and diseases in the environments in which the 
407 authors have also previously [31-34] reported the influence of these factors on the environmental classification. For Ramalho et al. [35], the most significant contributions to the GEI in the bean cultures were due to the combinations of cultivar $\times$ season and cultivar $\times$ years. genotypic and environmental information, in line with the advances in data collection and analysis. The first analyses were based on analysis of variance [36,37], with a single parameter to interpret the adaptability and stability. The advances with the development of new methodologies however, are based on regression analysis, with interpretations based on more parameters, such as the average, the regression coefficient, the regression deviation, and new definitions of adaptability and stability [4,7,38]. phenotypic values in regression with genetic markers and in environmental covariates, via mixed models [39]. However, these models based on regression, consider a priori that the genotype behavior is predetermined, based on linear regression equations, which may not equate to the genotypes actual behavior. Thus, reaction norm models in conjunction with Legendre polynomials are used to establish the order of the polynomials of the regression parameters later, according to the behavior of the genotypes in a series of environments (in a MET). Additionally, the mixed model approach also allows for the genotypic values of individuals to be predicted, as adaptability and stability are genotypic, and not phenotypic. genotypes over a period of time is described, mainly using covariance function information [40-42]. However, there are only a few studies in the literature that use reaction norm models with plants. 

individual's genetic effects with their exposure to the environmental effects, so that the genotypes are adjusted as a nonlinear function of a continuous environmental gradient. The adjustment of reaction norm models, as a function of the environmental gradient, considering Legendre polynomials, captures more adequately the behavior of the genotypes in a MET. The fact that an individuals' behavior is not predetermined, is an advantage of the proposed methodology in relation to the traditional methods of analysis of adaptability and stability. accuracy represents the reliability in the evaluation of the behavior of the evaluated genotypes 440 in different environments. In this work, most of the accuracy estimates obtained for each cultivar in each environment were greater than $80 \%$, which also resulted in an average accuracy of the 13 trials that was higher than this value. In the VCU trials, Resende and Duarte [23] recommended that the accuracy should be at least $80 \%$. Other previous investigations have also highlight the importance of prediction accuracies, using the reaction norm models in plant breeding experiments $[39,44,45]$.

Another advantage of the proposed methodology, using reaction norm models, is the prediction of genotypic values for the cultivars for environments in which they were not evaluated, when the MET presents genetic imbalance. When using experiments with unbalanced data, or just a sample of the cultivars, the prediction accuracy estimates tend to be lower, and the model may not be efficient in evaluating the performance of the cultivars $[46,47]$. 
For Smith et al. [49], using accurate information for the behavior of the cultivars,

allowed breeders to choose the best varieties, according to the needs of farmers, in order to

maximize profitability and food security. One of the difficulties in assessing the behavior of a

over the years, in addition to the loss of information due to problems that occurred over the trials, resulting in genetic and statistical imbalances. In this context, Resende $[16,50]$ states that the mixed model approach is a better alternative, for the analysis of such trials.

As noted, only 12 cultivars of superior performance were found in Fig 2-4, with eight carioca bean cultivars and four black bean cultivars, instead of 30 cultivars ( 10 per figure). This was because there were some cultivars that were widely adaptable and highly stable that were selected for more than one scenario, such as the IPR Campos Gerais and IPR Tuiuiú. not included in figures 2,3 , and 4 , as those selected by the reaction norm models. This can be explained by the fact that the methodology when calculating the probability of each cultivar that was based on the cultivar-ideotype distance penalizes cultivars that showed great variation in their productivity during the trials, even if they presented high general averages. Thus, the environments. Eeuwijk et al. and Van Oijen and Höglind [12,51] also reported this property of reaction norms. It is also worth mentioning that the use of the ideotype that was established from the data itself, had the advantage of comparing the genotypes with a real situation observed for that MET, since the ideotype is defined as the maximum value predicted in each trial.

477 the genetic variations and correlations between the environments, in addition to the spatial trends in the trials [22]. Furthermore, these models allow for more accurate estimations of the 
479 genotypes in the trials, as well as better estimations of the genetic parameters, such as 480 heritability, variances, covariances, and genetic correlations, while they become more difficult 481 in models with only fixed effects [12].

VCU tests are the basis for the recommendation of a cultivar and it is required that they are carried out in various locations, seasons, and years of the macro-region where the cultivar is being recommended. Thus, the recommended cultivars are those with higher general averages across the environments, that is, wide adaptability. Cultivars with these behavior, beyond the interests of the breeders making the recommendations, are also of interest to the farmers, as beans are mostly cultivated by small farmers, who buy grains from other producers and regions to use as seed. Thus, there is often an overlap and lack of control as to what the planting season and region actually are for a cultivar, and its official recommendations [52].

It is expected that cultivars with maximum adaptability to unfavorable environments will be more desirable for these unstructured conditions. These environments can be described as having low levels of technological investment, which can be normal in small-scale agriculture [3]. In addition, adverse conditions caused by the climate, such as a lack or excess of rain and incidence of pests and diseases also contribute to the characterization of environments as unfavorable. Thus, it is desirable that cultivars that are recommended for unfavorable environments maintain a satisfactory standard of productivity, even in stressful 497 situations, whether this is due to a lack or excess of any factor. However, in a situation of improvement of the environment, these cultivars will not be responsive to this increment of environmental quality. This illustrates the definition of adaptability as presented by Cruz et al.

$500[3]$, as the differential response of cultivars due to a stimulus from the environment. 
respond satisfactorily to environmental improvements, reaching high levels of yield in order to return the investment made, since these environments have high technological use, such as irrigation and precision agriculture, and are commonly run by large scale practices. However, observed that the strains VP 22 and VP 33 showed superior performance in environments classified as favorable. The fact that the experiments conducted by the Programa Feijão - UFV, who are responsible for the selection of these strains and always utilize optimal cultivation conditions (fertilization, irrigation, and pest and disease control), may explain this. to the environmental stimulus, being caused by the differential expression of the genes present in each individual. In this way, the adaptability and stability indicated in the reaction norm curves of the cultivars, provides information regarding their capacity to express phenotypes that may better adjust to the environmental conditions [53]. In this sense, one way to improve the adaptability of cultivars to the different environments in which they will be cultivated, is to pyramid the genes of maximum expression in both the unfavorable and favorable environments.

The superior cultivars in each studied scenario were developed in different breeding programs from four institutions (EMBRAPA, UFV, IAC, and IAPAR). This is indicative of the effort and success of these breeding programs, as well as the genetic diversity between them, since the breeding programs are independent, with their own parental lines. Possobom [54] demonstrated 522 that cultivars originating from the same institution are usually more related, while cultivars 523 from different institutions belong to different groups of dissimilarity. Thus, these outstanding 524 cultivars also have the potential to be used in bean improvement programs. 

appears to be an alternative in the evaluation of multi-environment trials, since it enables

530 genetic and statistical imbalances to be addressed, as well an improved evaluation of cultivar 531 behavior.

\section{Acknowledgments}

We would like to thank the students of the Programa Feijão for their contribution with the help of data collection for this work. We would like to thank the CNPq (Conselho Nacional de Desenvolvimento Científico e Tecnológico), FAPEMIG (Fundação de Amparo à Pesquisa do Estado de Minas Gerais) and CAPES (Coordenação de Aperfeiçoamento de Pessoal de Nível Superior) agencies for their financial support. We would like to thank Editage (www.editage.com) for English language editing.

\section{References}

544 1. Borém A, Miranda GV. Melhoramento de Plantas. 5th ed. Viçosa, MG: Editora UFV; 2009.

546 2. MAPA. Formulários para Registro de Cultivares - Ministério da Agricultura, Pecuária

Available: 
http://www.agricultura.gov.br/assuntos/insumos-agropecuarios/insumos-

agricolas/sementes-e-mudas/registro-nacional-de-cultivares-2013-rnc-1/formulariospara-registro-de-cultivares

3. Cruz CD, Regazzi AJ, Carneiro PCS. Modelos Biométricos Aplicados ao Melhoramento Genético. 4th ed. Viçosa, MG: Editora UFV; 2012.

4. Finlay K, Wilkinson G. The analysis of adaptation in a plant-breeding programme. Aust J Agric Res. 1963;14: 742. doi:10.1071/AR9630742

5. Eberhart SA, Russell WA. Stability Parameters for Comparing Varieties1. Crop Sci. 1966;6: 36. doi:10.2135/cropsci1966.0011183x000600010011x

6. Verma MM, Chahal GS, Murty BR. Limitations of conventional regression analysis a proposed modification. Theor Appl Genet. 1978;53: 89-91. doi:10.1007/BF00274335

7. Cruz CD., Torres RD., Vencovsky R. An alternative approach to the stability analysis proposed by Silva and Barreto. Rev Bras Genética. 1989;12: 567-580.

8. Rocha RB, Muro-Abad JI, Araújo EF, Cruz CD. Avaliação do método centróide para estudo de adaptabilidade ao ambiente de clones de Eucalyptus grandis. Ciência Florest. 2005; 15: 255-266. Available:

9. Nascimento M, Ferreira A, Mota Campana AC, Salgado CC, Cruz CD. Multiple Centroid Methodology to analyze genotype adaptability. Crop Breed Appl Biotechnol. 2009;9: 8-16. Available: https://search.proquest.com/docview/1936359411?pqorigsite $=$ gscholar

10. Nascimento M, Ferreira A, Nascimento ACC, Silva FF e, Ferreira R de P, Cruz CD, et al. Multiple centroid method to evaluate the adaptability of alfalfa genotypes. Rev Ceres. 
11. Oliveira RL de, Von Pinho RG, Ferreira DF, Pires LPM, Melo WMC. Selection index doi:10.1155/2014/360570

12. Eeuwijk FA Van, Bustos-korts D V, Malosetti M. What Should Students in Plant Breeding Know About the Statistical Aspects of Genotype ' Environment Interactions?

13. Gauch HG. Statistical analysis of regional yield trials: AMMI analysis of factorial designs. 1st ed. Gauch HGJ, editor. Ithaca, NY: Elsevier; 1992.

14. Yan W, Hunt LA. Interpretation of genotype $\mathrm{X}$ environment interaction for winter wheat yield in Ontario. Crop Sci. 2001;41: 19-25. Available:

15. Resende MD. Genética biométrica e estatística no melhoramento de plantas perenes. Brasília, DF: Embrapa Informação Tecnológica; 2002.

16. Resende MDV de. Análise Estatística de Modelos Mistos via REML/BLUP na Experimentação em Melhoramento De Plantas Perenes. Documentos. Colombo, PR:

17. Kirkpatrick M, Heckman N. A quantitative genetic model for growth, shape, reaction norms, and other infinite-dimensional characters. J Math Biol. 1989;27: 429-450. Available: https://link-springercom.ez35.periodicos.capes.gov.br/content/pdf/10.1007\%2FBF00290638.pdf

18. Akaike H. A new look at the statistical identification model. A new look Stat Identif 
Model. 1974;19: 716.

595

596

597

598

599

600

601

602

603

604

605

606

607

608

609

610

611

612

613

614

615

19. Wolfinger R. Covariance structure selection in general mixed models. Commun Stat Simul Comput. 1993;22: 1079-1106. doi:10.1080/03610919308813143

20. Stoica P, Babu P. Model order estimation via penalizing adaptively the likelihood (PAL). Signal Processing. 2013;93: 2865-2871. doi:10.1016/J.SIGPRO.2013.03.014

21. Rao CR. Linear statistical inference and its application. New York: John Wiley and Sons; 1965. Available: https://academic.oup.com/jlms/article-abstract/s1-42/1/382/844079

22. Kirkpatrick M, Lofsvold D, Bulmer M. Analysis of the inheritance, selection and evolution of growth trajectories. Genetics. 1990;124.

23. Resende MDV de, Duarte JB. Precisão e controle de qualidade em experimentos de avaliação de cultivares. Pesqui Agropecuária Trop. 2007;37: 182-194. Available: file://C:/Users/Sandrinho/Downloads/artículo_redalyc_253021631009.pdf

24. Carneiro JE de S, Paula Júnior TJ de, Borém A. Feijão, do plantio à colheita. Viçosa, MG: Editora UFV; 2015.

25. Melo CLP de, Carneiro, José Eustáquio de Souza Carneiro PCS, Cruz CD, Barros, Everaldo Gonçalves de Moreira MA. Linhagens de feijão do cruzamento "Ouro Negro" x "Pérola" com características agronômicas favoráveis. Pesqui Agropecuária Bras. 2006;41: 1593-1598.

Available:

http://www.scielo.br/pdf/\%0D/pab/v41n11/a04v4111.pdf

26. Gilmour AR, Gogel BJ, Cullis BR, Welham SJ, Thompson R. ASReml User Guide Release 4.1 Structural Specification,. VSN International Ltd, Hemel Hempstead, HP1 1ES, UK www.vsni.co.uk. 2015. Available: www.vsni.co.uk 
27. Computing RF for S. R Development Core Team. Austria, vienna; 2015.

617

618

619

620

621

622

623

624

625

626

627

628

629

630

631

632

633

634

635

636

637

638

28. Yang Y. Can the strengths of AIC and BIC be shared? A conflict between model indentification and regression estimation. Biometrika. 2005;92: 937-950. doi:10.1093/biomet/92.4.937

29. Corrales JD, Munilla S, Cantet RJC. Polynomial order selection in random regression models via penalizing adaptively the likelihood. J Anim Breed Genet. 2015;132: 281288. doi:10.1111/jbg.12130

30. Vrieze SI. Model selection and psychological theory: A discussion of the differences between the Akaike information criterion (AIC) and the Bayesian information criterion (BIC). Psychol Methods. 2012;17: 228-243. doi:10.1037/a0027127

31. Barili LD, Vale NM do, Amaral R de C, Carneiro JE de S, Silva FF e, Carneiro PCS. Adaptabilidade e estabilidade e a produtividade de grãos em cultivares de feijão preto recomendadas no Brasil nas últimas cinco décadas. Ciência Rural. 2015;45: 1980-1986. doi:10.1590/0103-8478cr20141383

32. Melo LC, Guimarães P, Melo S, Faria LC De, Luiz J, Diaz C. Interação com ambientes e estabilidade de genótipos de feijoeiro-comum na Região Centro-Sul do Brasil. Pesqui Agropecu Bras. 2007; 715-723.

33. Moura MM, Carneiro PCS, Carneiro JE de S, Cruz CD. Potencial de caracteres na avaliação da arquitetura de plantas de feijão. Pesqui Agropecuária Bras. 2013;48: 417425. doi:10.1590/S0100-204X2013000400010

34. Ribeiro ND, Antunes IF, Souza JF de, Poersch NL. Adaptação e estabilidade de produção de cultivares e linhagens-elite de feijão no Estado do Rio Grande do Sul. Ciência Rural. 2008;38: 2434-2440. doi:10.1590/S0103-84782008005000018 
639 35. Ramalho MAP, Abreu A de FB, Santos PSJ dos. Interações genótipos x épocas de semeadura, anos e locais na avaliação de cultivares de feijão nas regiões Sul e Alto Paranaíba em Minas Gerais. Ciência e Agrotecnologia. 1998;22: 175-181. Available: https://www.alice.cnptia.embrapa.br/alice/bitstream/doc/1017707/1/ca19980001.pdf

36. Wricke G. Zur Berechnung der Ökovalenz bei Sommerweizen und Hafer. Pflanzenzuchtung,. 1965;52: 127-138.

37. Plaisted RL, Peterson LC. A technique for evaluating the ability of selections to yield consistently in different locations or seasons. Am Potato J. 1959;36: 381-385.

38. Eberhart SA, Russell WA. Stability Parameters for Comparing Varieties1. Crop Sci. 1966;6: 36. doi:10.2135/cropsci1966.0011183X000600010011x

39. Jarquín D, Crossa J, Lacaze X, Du Cheyron P, Daucourt J, Lorgeou J, et al. A reaction norm model for genomic selection using high-dimensional genomic and environmental

40. Meyer K. Estimating covariance functions for longitudinal data using a random regression model.

41. Jamrozik J, Schaeffer LR, Dekkers JCM. Genetic Evaluation of Dairy Cattle Using Test

42. Schaeffer LR. Application of random regression models in animal breeding. [cited 11 Dec 2019]. doi:10.1016/S0301-6226(03)00151-9

43. Ni G, van der Werf J, Zhou X, Hyppönen E, Wray NR, Lee SH. Genotype-covariate correlation and interaction disentangled by a whole-genome multivariate reaction norm 
model. Nat Commun. 2019;10. doi:10.1038/s41467-019-10128-w

663

664

665

666

667

668

669

670

671

672

673

674

675

676

677

678

679

680

681

682

683

684

44. Burgueño J, de los Campos G, Weigel K, Crossa J. Genomic Prediction of Breeding Values when Modeling Genotype $\times$ Environment Interaction using Pedigree and Dense Molecular Markers. Crop Sci. 2012;52: 707. doi:10.2135/cropsci2011.06.0299

45. Pérez-Rodríguez P, Crossa J, Bondalapati K, De Meyer G, Pita F, Campos G de los. A pedigree-based reaction norm model for prediction of cotton yield in multienvironment trials. Crop Sci. 2015;55: 1143. doi:10.2135/cropsci2014.08.0577

46. Lian L, Jacobson A, Zhong S, Bernardo R. Genomewide prediction accuracy within 969 maize biparental populations. Crop Sci. 2014;54: 1514-1522. doi:10.2135/cropsci2013.12.0856

47. Lorenzana RE, Bernardo R. Accuracy of genotypic value predictions for marker-based selection in biparental plant populations. Theor Appl Genet. 2009;120: 151-161. doi:10.1007/s00122-009-1166-3

48. Cargnelutti Filho A, Storck L. Medidas do grau de precisão experimental em ensaios de competição de cultivares de milho. Pesqui Agropecuária Bras. 2010;44: 111-117. Available: http://seer.sct.embrapa.br/index.php/pab/article/view/1486/5654

49. Smith AB, Ganesalingam A, Kuchel H, Cullis BR. Factor analytic mixed models for the provision of grower information from national crop variety testing programs. Theor Appl Genet. 2015;128: 55-72. doi:10.1007/s00122-014-2412-x

50. Resende MDV de. Genética biométrica e estatística no melhoramento de plantas perenes. Emprapa Informação Tecnológica; 2002. Available: https://www.bdpa.cnptia.embrapa.br/consulta/busca?b=pc\&id=306061\&biblioteca=vaz io\&busca=autoria:\%22RESENDE, M.\%22\&qFacets=autoria:\%22RESENDE, 
51. Van Oijen M, Höglind M. Toward a Bayesian procedure for using process-based models in plant breeding, with application to ideotype design. Euphytica. 2016;207: 627-643. doi:10.1007/s10681-015-1562-5

52. Carbonell SAM et al. Adaptabilidade e estabilidade de produção de cultivares e linhagens de feijoeiro no Estado de São Paulo. Bragantia. 2001;60: 69-77. Available: https://www.redalyc.org/html/908/90813494002/

53. Xue B, Leibler S. Benefits of phenotypic plasticity for population growth in varying environments. Proc Natl Acad Sci U S A. 2018;115: 12745-12750. doi:10.1073/pnas.1813447115

54. Possobom MTDF. Diversidade genética de linhagens de feijão preto e "carioca" recomendadas no Brasil nos últimos 50 anos. UFV. 2018.

S1 Table. Carioca bean cultivars, institutions of origin and year of recommendation.

S2 Table: Black bean cultivars, institutions of origin and year of recommendation.

S4 Table: Accuracy of 105 cultivars in each trial. 


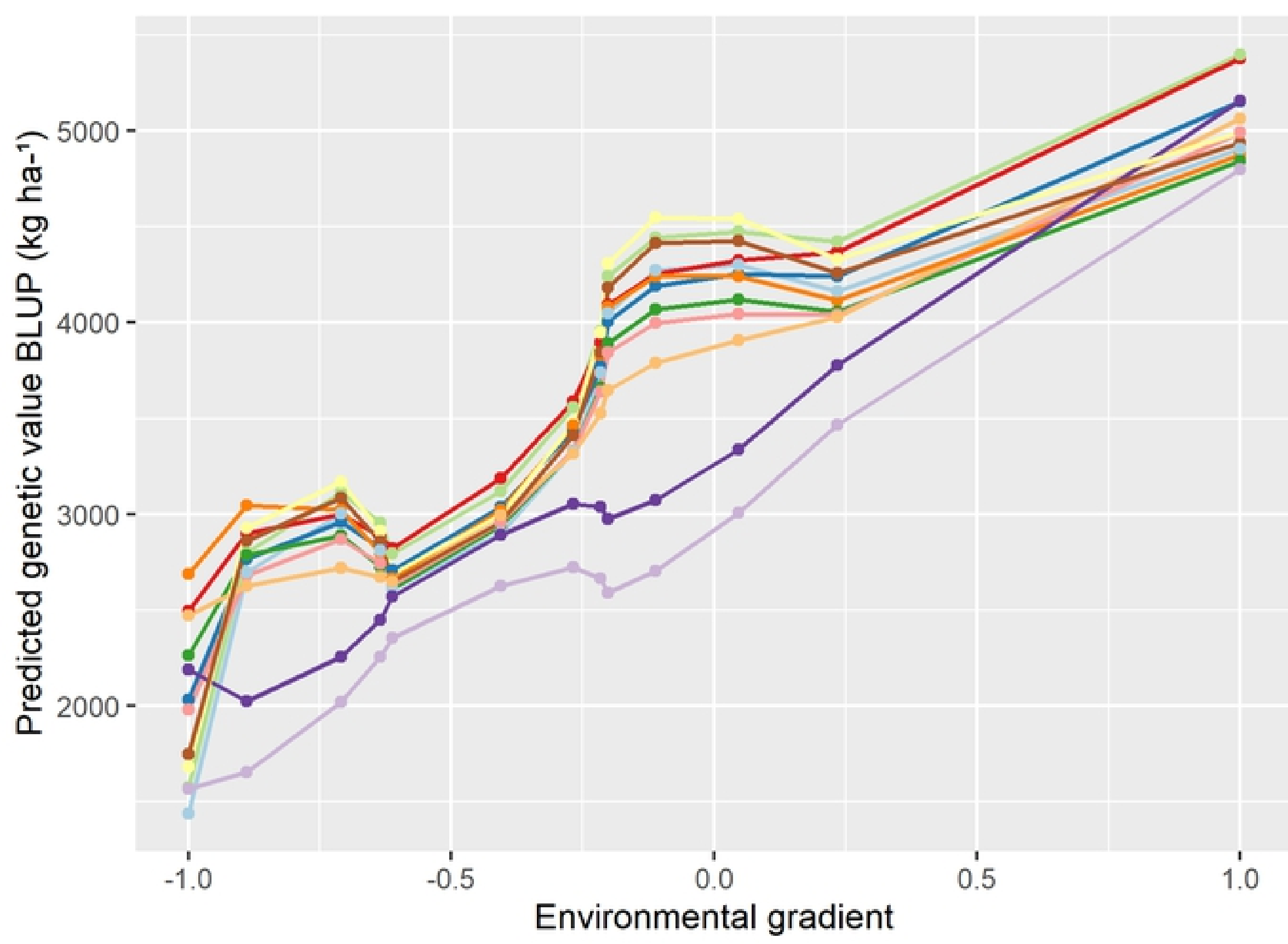

Cultivars

$\because$ BRS Agreste

$\multimap$ BRS Estilo

$\rightarrow$ IAC Formoso

$\rightarrow$ IAC Imperador

$\because$ IPR Andorinha

$\rightarrow$ IPR Campos Gerais

$\because$ IPR Tiziu

$\because$ IPR Tuiuiú

$\rightarrow$ Ouro Negro*

$\rightarrow$ Pérola* $^{*}$

VC 15

$\rightarrow$ VP 22

Fig 2 


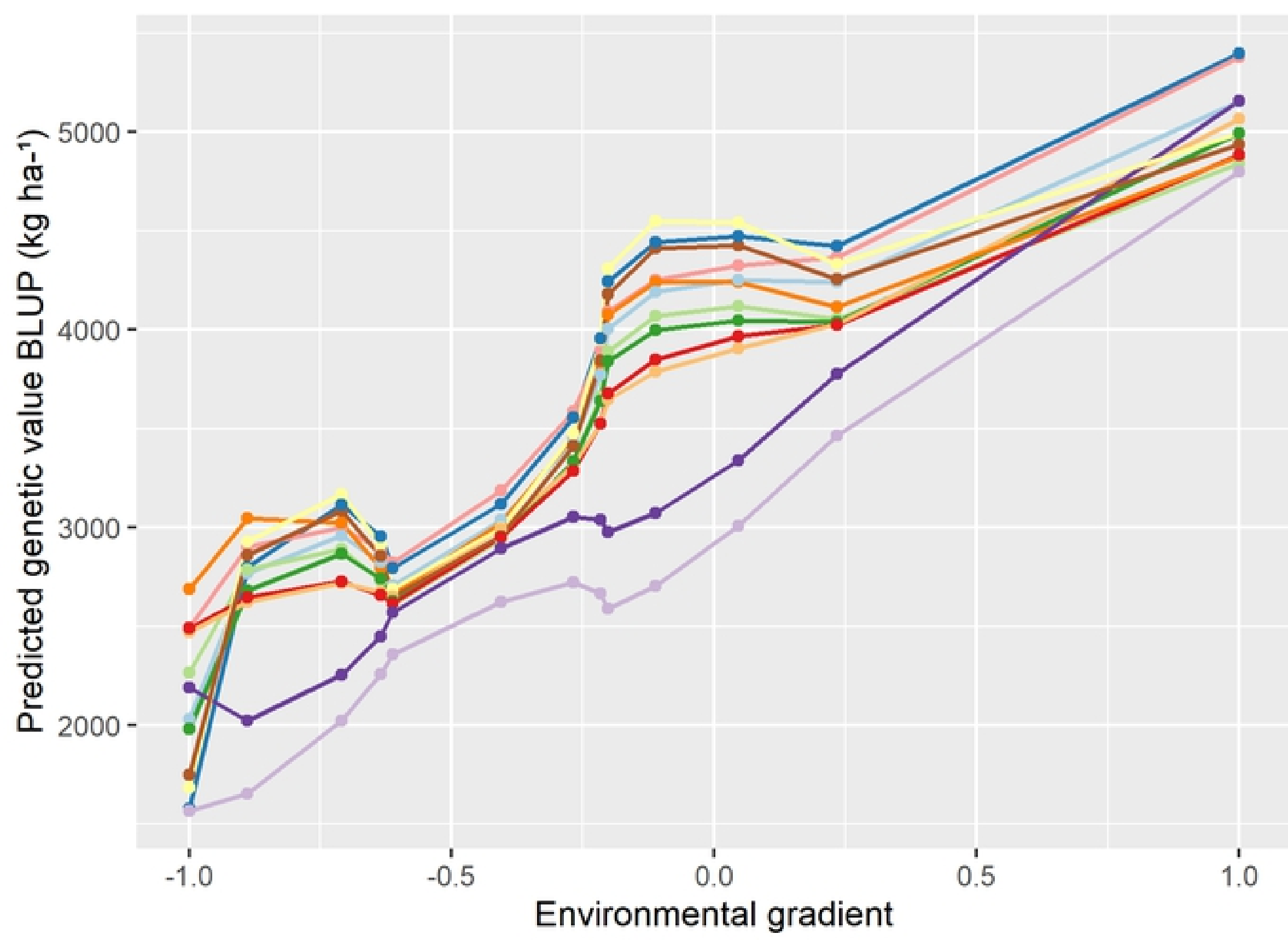

Cultivars

$\because$ BRS Estilo

$\rightarrow$ IAC Formoso

- IAC Imperador

$\rightarrow$ IPR Andorinha

$\rightarrow \quad$ IPR Campos Gerais

$\rightarrow$ IPR Tangará

$\because$ IPR Tiziu

- IPR Tuiuiú

$\rightarrow$ Ouro Negro*

$\rightarrow$ Pérola*

VC 15

$\rightarrow$ VP 22

Fig 3 


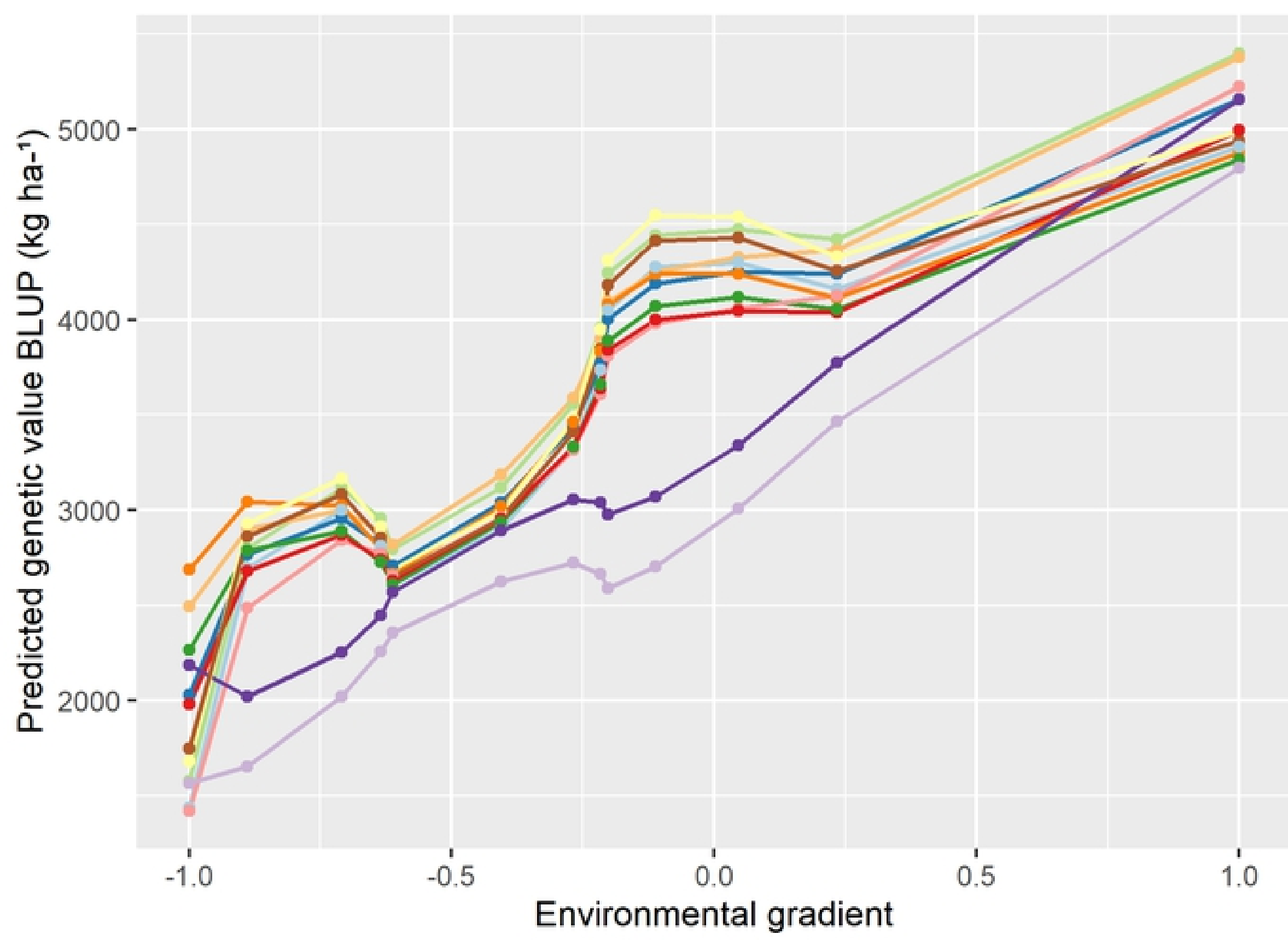

Cultivars

$\because$ BRS Agreste

$\multimap$ BRS Estilo

$\because$ IAC Formoso

$\rightarrow$ IAC Imperador

$\because$ IPR 139

$\rightarrow$ IPR Andorinha

- IPR Campos Gerais

$\because$ IPR Tuiuiú

$\rightarrow$ Ouro Negro*

$\rightarrow$ Pérola*

VC 15

$\because$ VP 22

Fig 4 